\title{
Anemia in Children under Five Years Old in Eastern Cuba, 2005-2011
}

\author{
Gisela M. Pita MD MS, Santa Jiménez MD PhD, Beatriz Basabe MS PhD, René G. García MD, Consuelo Macías PhD, \\ Lisette Selva MD, Clarisa Hernández MD, Margarita Cruz, Roxana Herrera MD MS, Regla O'Farrill MD, Isabel Calderius, \\ Karelia Paulí MD, Moraima Leyva, Caridad Arocha, Dania Herrera
}

\begin{abstract}
INTRODUCTION Anemia is the main nutritional problem in Cuban preschool children, prompting several interventions to prevent and control it. An enhanced national strategy was established in 2008, and particular attention paid to the eastern provinces, the region with greatest challenges in social determinants of health.
\end{abstract}

OBJECTIVE Determine anemia prevalence in children aged 6-59 months in Cuba's five eastern provinces in three separate years within a decade, as well as association of anemia with epidemiological and nutritional factors, to assess impact of Cuba's Comprehensive Plan for Prevention and Control of Iron-Deficiency Anemia in Cuba.

METHODS Cross-sectional studies of children aged 6-59 months (completed) were conducted in 2005, 2008 and 2011. Hemoglobin levels were measured to diagnose anemia (hemoglobin $<110 \mathrm{~g} / \mathrm{L}$ ) and data were collected on independent variables such as age, sex, area of residence (urban or rural), daycare center enrollment, birth weight, breastfeeding history, and maternal anemia during pregnancy. Frequency distributions were created and comparisons tested with the chi square, and odds ratios calculated with $95 \%$ confidence intervals.

RESULTS Anemia prevalence in the region fell from $31.8 \%$ in 2005 to $26 \%$ in 2011; most of cases were mild (hemoglobin: $100-109 \mathrm{~g} / \mathrm{L}$ ).
Prevalence was higher in children aged 6-23 months than in those aged 24-59 months throughout. No significant differences were found in anemia prevalence between boys and girls. Prevalence was higher in rural than in urban areas in $2005(p=0.026)$ and $2011(p=0.012)$. Daycare enrollment emerged as a protective factor in all three years. Low birth weight was associated with anemia only in 2011 (OR 1.74, $\mathrm{Cl}$ 1.04-2.92). Prevalence of exclusive breastfeeding for six months increased over the study period; lack of breastfeeding was found to be associated with anemia in 2005 (OR 1.57, Cl 1.05-2.34). Maternal anemia at onset of and during pregnancy was a significant risk factor in 2005 (OR 1.98, Cl 1.27-3.10) and 2011 (OR 1.43, Cl 1.05-1.94).

CONCLUSIONS Although anemia prevalence steadily decreased over the study period, it continues to be a public health problem in Cuba and anemia prevention and control measures should be maintained and strengthened: interventions for women of childbearing age, fostering exclusive breastfeeding of infants through their sixth month, and encouraging compliance with recommendations on complementary feeding per Cuba's nutritional guidelines for children aged $<2$ years. Further evaluation is needed to identify the causes of anemia in the population of preschool children.

KEYWORDS Anemia; children, preschool; infants; breastfeeding; child daycare centers; Cuba

\section{INTRODUCTION}

Causes of anemia can be multifactoral and often coincide, but the primary cause is a diet with inadequate iron sources (quantitatively and qualitatively); iron deficiency causes an estimated $50 \%$ of anemia cases worldwide.[1]

Iron is an essential mineral in basic neural processes such as myelination, production of neurotransmitters, and energy metabolism.[2] Fetal iron stores accumulate in the third trimester of pregnancy. Iron content is directly proportional to body mass, so newborns with low birth weight have less total iron available. Hence the importance of monitoring iron status during pregnancy and ensuring that delivery procedures avoid premature clamping of the umbilical cord to prevent iron deficiency. [3] Rapid neural development occurs in the first year of life, when morphological, biochemical and bioenergetic changes can affect all central nervous system functions. Iron is critical at this stage for neurogenesis and cell differentiation in various areas of the brain.[4]

Iron-deficiency anemia is the final stage of iron deficiency that, if occurring during the critical period (aged $<2$ years) without early intervention, can cause irreversible damage, preventing the child from reaching neurodevelopmental milestones.[5-7]

WHO has developed a classification system to facilitate international comparisons of anemia as a public health problem. The problem is considered severe if anemia prevalence is $\geq 40 \%$, moderate from $20 \%$ to $39.9 \%$, and mild from $5 \%$ to $19.9 \%$.[8] In
Cuba, iron-deficiency anemia is the main specific nutritional problem, classified as moderate in children aged $<5$ years.[9] A national study of children aged 6-35 months conducted in 2006-2007 revealed anemia prevalence of $37.5 \%$.[10]

Since 1987, population-level and targeted interventions have been implemented in Cuba to reduce iron deficiency and iron-deficiency anemia.[9] It has been shown that fortifying foods with iron constitutes one of the main cost-effective approaches to anemia prevention.[1,11] Many Latin American countries use food fortified with iron and other micronutrients, promoting consumption in specific population groups such as children.[12,13] The Cuban government has designated priority groups for subsidized food sales at local groceries nationwide, providing children aged six months to three years with iron- and vitamin C-fortified fruit purees since 2003, and iron- and zinc-fortified milk since 2005.[8,14,15]

These actions are now part of the Comprehensive Plan for Prevention and Control of Iron-Deficiency Anemia in Cuba (established in 2008) in the general population, prioritizing high-risk groups. In addition to fortified foods, the Plan involves strategies such as dietary supplements, food diversification, and surveillance to monitor iron-deficiency anemia and to evaluate intervention effectiveness.[16,17]

UN agencies have cooperated in these efforts through a number of programs:

- Food Assistance Project \#10032 (financed by the World Food Programme, 2002-2008),[18] including introduction in 2006 of 
iron- and vitamin-fortified Corn Soya Blend (CSB), a vitaminand iron-fortified food for children aged $<5$ years; [18]

- Project\#10589 to support the national Plan among children aged $<5$ years in Cuba's five eastern provinces (2008-2012);[19] and

- A multiagency project to combat anemia in vulnerable groups (2009-2013).[20,21]

Eastern Cuba has been the object of UN agency and Cuban authorities' attention in this area, as the region with the greatest challenges in social determinants of health. Vulnerability studies in eastern Cuba have examined the role of food insecurity in the prevalence of malnutrition in children aged $<5$ years, analyzing various indicators: socioeconomic (such as population, average salary, commercial production), environmental (drought, flooding, soil quality, water supply, food production) and human development (low birth weight, participation of women in the workforce).[22]

Depending on the type of nutritional problem at issue, hemoglobin may not always be the most appropriate indicator for anemia, due to its low sensitivity to iron deficiency (hemoglobin levels often overlap in iron-deficient and healthy individuals). Its specificity is also poor, since iron deficiency is only one of many disorders that can cause anemia.[23-25] Despite this constraint, in Cuba, as in many developing countries with high prevalence of iron deficiency, hemoglobin levels can be an appropriate, inexpensive and simple indicator of iron status and anemia.

The objective of our research was to determine anemia prevalence and association of anemia with nutritional factors in children aged 6-59 months in Cuba's five eastern provinces, enabling evaluation of the impact of the various interventions of the Comprehensive Plan for Prevention and Control of Iron-Deficiency Anemia.

\section{METHODS}

A three-phase, descriptive, cross-sectional study was designed, which included intermediate and final evaluations of the Cuban government's food assistance project (\#10032), with support from the World Food Programme (WFP), and an evaluation of the project to support work of the Comprehensive Plan for Prevention and Control of Iron-Deficiency Anemia in Cuba's five eastern provinces (\#10589, also supported by WFP). Research was conducted in the first semesters of 2005, 2008 and 2011, in the provinces of Las Tunas, Holguín, Granma, Santiago de Cuba and Guantánamo.

Universe and sample The universe was composed of preschool children (aged 6 months to 59 months (completed; i.e., until day before fifth birthday) in Cuba's five eastern provinces (an estimated 263,252 children aged $<5$ years). [24] The sample in each province was selected considering the child's area of residence (urban or rural) and enrollment (or not) at a daycare center.

Sampling We used a stratified multistage cluster design in which strata included province, area of residence (urban or rural), municipality and daycare enrollment. Municipalities were the primary sampling units, family doctor-and-nurse offices (CMF, the Spanish acronym) were the secondary sampling units, and individual children constituted the units of analysis. To calculate the sample size needed, we used the National Statistics Bureau's population estimates for children aged $<5$ years in urban $(n=162,565)$ and rural areas ( $n=100,687$ ) in the country's five eastern provinces,[26] assuming anemia prevalence of $35 \%$ and accepting a $10 \%$ margin of error for a $95 \%$ confidence interval.
As it was a complex sample, a design effect of 1.5 was applied and to compensate for sample attrition, sample size was increased by approximately $10 \%$. The final total desired sample was 2350, with 1175 children in urban and 1175 in rural areas. For practical reasons, the sample was evenly distributed across the 5 provinces: 470 children per province, also evenly divided between urban and rural areas (235 in each). Within each area (urban and rural) of the province, municipal distribution was proportional to population size in 4 or 5 municipalities accounting for approximately $40 \%$ of municipalities in each province (randomly selected, except that the provincial capital was always included, because of its high population density). Within each area in a municipality, the sample was further divided between children enrolled in day care and those who were not $(30 \%$ and $70 \%$, respectively); because hard data were not available, daycare accordance was estimated by a key informant (personal communication, Mercedes Leiva, preschool education department of Cuba's Ministry of Education).

Municipalities selected by province were:

Las Tunas: Puerto Padre, Tunas, Jobabo and Amancio

Rodríguez

Holguín: Banes, Holguín, Calixto García, Cueto and Sagua de Tánamo

Granma: Jiguaní, Bayamo, Manzanillo, Campechuela and

Niquero

Santiago de Cuba: San Luis, Santiago de Cuba, Palma

Soriano and Tercer Frente

Guantánamo: Guantánamo, Niceto Pérez, Baracoa and San

Antonio

In each municipality, $20 \%$ of CMFs were selected by phased systematic sampling, to ensure that selected offices were evenly distributed throughout the municipality; children were selected from CMF rosters, using updated lists from the latest annual polio vaccination campaign. In areas without daycare centers, the population that would have been included in these was deemed sample loss.

This sampling strategy was also applied in the 2008 and 2011 studies, enabling comparison of results.

Inclusion/exclusion criteria All apparently healthy children in the target group at the time of sample selection were included.

Study variables The dependent variable was anemia $(\mathrm{Hb}<110$ $\mathrm{g} / \mathrm{L}$ ); independent variables were age, sex, area of residence (urban, rural), and daycare center enrollment. For children aged 6-23 months, nutritional variables potentially associated with anemia were evaluated: birth weight, exclusive breastfeeding for six months, and maternal anemia during pregnancy. We assessed the effect of ever having been breastfed in the third survey in 2011 (Table 1).[8,27,28]

Hemoglobin measurement Blood was collected by fingerprick, a standard technique for anemia prevalence field studies. Testing was done with the HemoCue $\beta$-Hemoglobin System (blood hemoglobin photometer, HemoCue 201+; Ängelholm, Sweden) using microwells with dry reagent and battery-run equipment.[29-31] Technicians performing this procedure were trained and certified prior to each step of the work to minimize errors in test-retest reliability, and were also provided with an instruction manual. 
Table 1: Study variables

\begin{tabular}{|c|c|}
\hline Variable & Category \\
\hline $\begin{array}{l}\text { Age group } \\
\text { (months completed) }\end{array}$ & $\begin{array}{l}6-11 \\
12-23 \\
24-59\end{array}$ \\
\hline Sex & Male, female \\
\hline Area of residence & Urban, rural \\
\hline Day care center enrollment & Yes, No \\
\hline Anemia & $\begin{array}{l}\text { Yes: } \mathrm{Hb}<110 \mathrm{~g} / \mathrm{L}[8] \\
\text { No: } \mathrm{Hb} \geq 110 \mathrm{~g} / \mathrm{L}\end{array}$ \\
\hline Severity of anemia & $\begin{array}{l}\text { Severe: } \mathrm{Hb}<70 \mathrm{~g} / \mathrm{L} \\
\text { Moderate: } \mathrm{Hb} 70-99 \mathrm{~g} / \mathrm{L} \\
\text { Mild: } \mathrm{Hb} 100-109 \mathrm{~g} / \mathrm{L}[8]\end{array}$ \\
\hline \multicolumn{2}{|c|}{ Nutritional variables (for children aged 6-23 months) } \\
\hline Birth weight[27] (g) & $\begin{array}{l}\text { Low }<2500 \\
\text { Normal } 2500 \text { to } 4000 \\
\text { Macrosomia }>4000\end{array}$ \\
\hline $\begin{array}{l}\text { Exclusively breastfed for } \\
\text { first } 6 \text { months }\end{array}$ & Yes, No \\
\hline $\begin{array}{l}\text { Ever breastfed } \\
\text { (assessed only in 2011) }\end{array}$ & $\begin{array}{l}\text { Proportion who had ever been } \\
\text { breastfed[28] }\end{array}$ \\
\hline $\begin{array}{l}\text { Maternal anemia during } \\
\text { pregnancy }\end{array}$ & $\begin{array}{l}\text { At onset of pregnancy } \\
\text { In } 2 \text { nd or 3rd trimester } \\
\text { No }\end{array}$ \\
\hline $\mathrm{Hb}$ : hemoglobin & \\
\hline
\end{tabular}

Data collection and management A standard form and database, designed by trained and certified personnel at the Nutrition and Food Hygiene Institute (INHA, the Spanish acronym), were used to collect and manage nutritional data. Birth weight was taken from the health record used in well child visits. Data on exclusive breastfeeding and mother's history of anemia at onset or in second or third trimester of pregnancy were collected by direct interview in which the mother was asked about the number of months of breastfeeding and her hemoglobin during pregnancy.

In each province, an Excel database was created and forwarded to INHA. SPSS version 13.0 was used for frequency distributions, anemia prevalence (\%) with confidence intervals, and for provincial comparisons using the chi-square test.[32] Epi-Info version 3.3 was used to calculate odds ratios and $95 \%$ confidence intervals to determine strength of association and statistical significance between anemia and independent variables.

Ethical considerations The project was approved by the INHA ethics committee and authorized by the National Pediatrics Expert Group and the Maternal-Child Division of the Ministry of Public Health. Written informed consent was obtained from parents or guardians of participating children. All children identified as anemic during the study were referred for treatment to their family doctors, who also received their patients' laboratory reports. prevalence was highest in children aged $<2$ years, and higher in the group aged $6-11$ months $(62.1 \%)$ than in the group aged $12-23$ months (52.8\%) (Table 2).

In 2008, the sample included 2121 children (Table 2). Anemia prevalence was $24 \%$, significantly lower than that observed in 2005 ( $p<0.001$ ); prevalence was highest in the provinces of Guantánamo and Holguín (Figure 1). There were statistically significant decreases in Guantánamo, Santiago and Granma compared with $2005(p<0.005)$. Anemia prevalence in the group aged $6-11$ months $(50.1 \%)$ was significantly less than in $2005(p=$ $0.004)$. Similarly, a reduction was observed in anemia prevalence in children aged $12-23$ months (from $52.8 \%$ to $32.7 \%$, p < 0.001 ) and aged $24-59$ months (from $19.8 \%$ to $12.2 \%, p<0.001$ ). In the group aged $24-59$ months, a relatively greater drop in anemia prevalence was observed $(38.4 \%)$ than in the group aged 6-23 months (29.1\%).

Figure 1: Anemia prevalence in children aged 6-59 months, by province

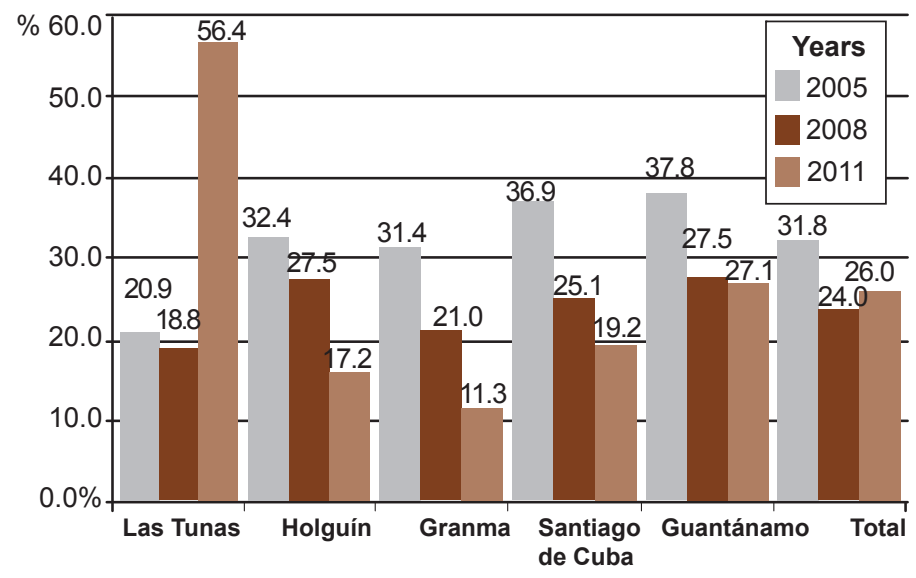

The 2011 sample included 2204 children (Table 2). Anemia prevalence was $26 \%$, for a relative increase of $8.3 \%$ compared with 2008. Anemia prevalence was $44.3 \%$ in the group aged 6-11 months, a nonsignificant reduction from 2008 ( $p=$ $0.174)$. In the group aged $12-23$ months, prevalence was $37.4 \%$, higher than in $2008(p=0.107)$. Anemia prevalence increased significantly from 2008 to 2011 to $17 \%$ in the group aged $24-59$ months $(p<0.001)$, but there was substantial provincial variation (Figure 1).

Prevalence tripled in Las Tunas (from $18.8 \%$ to $56.4 \%$ ); the change in Guantánamo was nonsignificant; and significant improvements were observed in Granma, Holguín and Santiago de Cuba (relative decreases of $46.2 \%, 37.5 \%$ and $23.5 \%$, respectively; $p<0.005)$. The greatest reductions in anemia prevalence

\section{RESULTS}

Anemia prevalence by province and age group In 2005, the sample included 2016 children (Table 2); $31.8 \%$ of whom were anemic. Anemia prevalence was highest in the provinces of Guantánamo and Santiago de Cuba (Figure 1). Anemia
Table 2: Anemia prevalence in children aged 6-59 months in eastern Cuba (2005, 2008 and 2011)

\begin{tabular}{|c|c|c|c|c|c|c|c|c|c|c|}
\hline \multirow{3}{*}{\multicolumn{2}{|c|}{$\begin{array}{l}\text { Age group } \\
\text { (months) }\end{array}$}} & \multicolumn{3}{|c|}{2005} & \multicolumn{3}{|r|}{2008} & \multicolumn{3}{|r|}{2011} \\
\hline & & \multirow{3}{*}{$\begin{array}{l}\mathbf{N} \\
240\end{array}$} & \multicolumn{2}{|r|}{ Anemic } & \multirow{3}{*}{$\begin{array}{l}\mathrm{N} \\
365\end{array}$} & \multicolumn{2}{|r|}{ Anemic } & \multirow{3}{*}{$\frac{N}{264}$} & \multicolumn{2}{|r|}{ Anemic } \\
\hline & & & $n$ & $\%(95 \% \mathrm{Cl})$ & & $n$ & $\%(95 \% \mathrm{Cl})$ & & $n$ & $\%(95 \% \mathrm{Cl})$ \\
\hline \multirow{3}{*}{$6-23$} & 6 to 11 & & 149 & $62.1(56.1-68.7)$ & & 183 & $50.1(45.0-55.2)$ & & 117 & $44.3(38.3-50.3)$ \\
\hline & 12 to 23 & 430 & 227 & $52.8(48.6-58.2)$ & 538 & 176 & $32.7(28.7-36.7)$ & 620 & 232 & $37.4(33.6-41.2)$ \\
\hline & Total & 670 & 376 & $56.1(52.3-59.9)$ & 903 & 359 & $39.8(36.6-43.0)$ & 884 & 349 & $39.5(36.3-42.7)$ \\
\hline \multicolumn{2}{|c|}{$24-59$} & 1346 & 266 & $19.8(17.7-21.9)$ & 1218 & 149 & $12.2(10.4-14.0)$ & 1320 & 224 & $17.0(15.0-19.0)$ \\
\hline \multicolumn{2}{|l|}{ Total } & 2016 & 642 & $31.8(29.8-33.8)$ & 2121 & 508 & $24.0(22.2-25.8)$ & 2204 & 573 & $26.0(24.2-27.8)$ \\
\hline
\end{tabular}


in the group aged 6-23 months were in Granma and Santiago de Cuba ( $47.4 \%$ and $34.7 \%$, respectively); the smallest was in Guantánamo, $7 \%$. In Holguín, the largest decrease (58.4\%) was in the group aged $24-59$ months. In Las Tunas, anemia prevalence doubled in the group aged 6-23 months and quadrupled in the group aged 24-59 months.

Most anemia cases were classified as mild in all three surveys, (64\% in $2005 ; 76.2 \%$ in $2008 ; 70.7 \%$ in 2011 ); moderate anemia constituted $35.7 \%$ of cases in $2005 ; 23.4 \%$ in 2008 ; and $29.3 \%$ in 2011. In 2005 and 2008 , only $0.3 \%$ and $0.4 \%$ of cases, respectively, were severe ( $n=1$ in both years). There were no cases of severe anemia in 2011.

Sex None of the three surveys found statistically significant differences for anemia prevalence by sex. In 2005, prevalence was $33 \%$ in boys and $31 \%$ in girls ( $p=0.337$ ); in $2008,24.2 \%$ in boys and $23.8 \%$ in girls ( $p=0.440)$; and in $2011,26.5 \%$ in boys and $25.5 \%$ in girls $(p=0.594)$. Nor were significant differences by sex observed in any of the surveys in the group aged $6-11$ months (2005: $p=0.501 ; 2008: p=0.601 ; 2011: p=1.000)$, an age group in which higher rates have been reported in boys.

Urban-rural residence In 2005, anemia prevalence was higher in rural than in urban areas $(34.4 \%$ vs. $29.8 \%, p=0.026)$. The difference was smaller and nonsignficant in $2008(25.8 \%$ vs. $22.5 \%, p=0.077$ ). In 2011, prevalence was again higher in rural areas than in urban areas $(28.5 \%$ vs. $23.5 \%, p=0.012)$ (Figure 2). No significant differences between rural and urban areas were observed in the group aged 6-23 months.

Day care Daycare centers were found in all urban areas studied. In three provinces, however, there were daycare centers only in some municipalities: Bayamo and Manzanillo in Granma; San Luis and Santiago in Santiago de Cuba Province; and Guantánamo in Guantánamo Province. The resulting sample shortfall in rural areas without daycare centers was $23 \%$.

In all three years, less than $20 \%$ of all children were enrolled in day care (2005: $19.1 \%$ in $2005,19.8 \%$ in 2008 , and $18.4 \%$ in 2011). Daycare enrollment was revealed as a protective factor for anemia in all three years of the study, with significantly lower anemia prevalence than in the non-daycare group (Table 3).

Figure 2: Anemia prevalence in children aged 6-59 months, by urban/rural residence

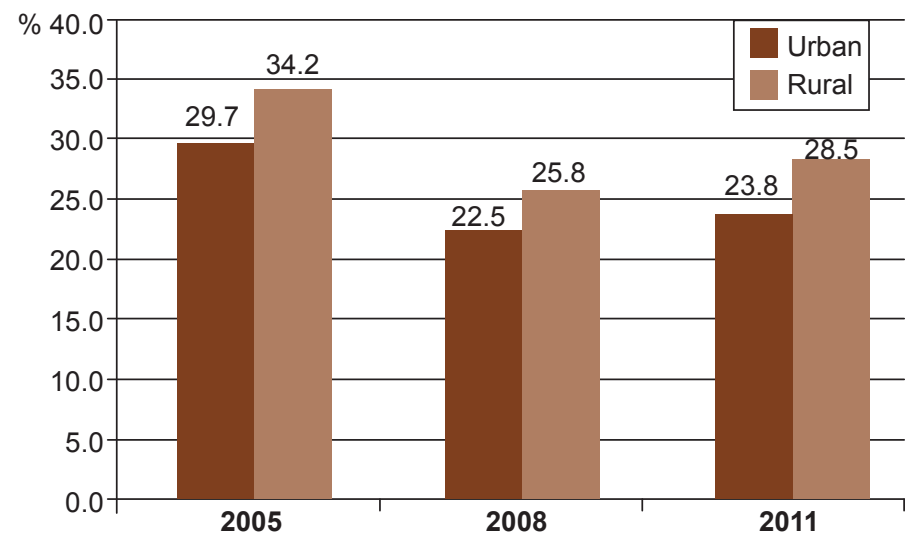

Table 3: Anemia prevalence in children aged 6-59 months, by daycare enrollment

\begin{tabular}{|c|c|c|c|c|c|c|c|c|c|}
\hline \multirow{3}{*}{$\begin{array}{l}\text { Daycare } \\
\text { enrollment }\end{array}$} & \multicolumn{3}{|c|}{$\begin{array}{c}2005 \\
\left(n=2013^{*}\right)\end{array}$} & \multicolumn{3}{|c|}{$\begin{array}{c}2008 \\
(n=2121)\end{array}$} & \multicolumn{3}{|c|}{$\begin{array}{c}2011 \\
(n=2204)\end{array}$} \\
\hline & \multirow{2}{*}{$\mathbf{N}$} & \multicolumn{2}{|c|}{ Anemic } & & \multicolumn{2}{|c|}{ Anemic } & & \multicolumn{2}{|c|}{ Anemic } \\
\hline & & $n$ & $\%$ & $\mathbf{N}$ & $n$ & $\%$ & $\mathbf{N}$ & $n$ & $\%$ \\
\hline No & 1624 & 578 & 35.6 & 1701 & 465 & 27.3 & 1798 & 527 & 29.3 \\
\hline Yes & 389 & 64 & 16.5 & 420 & 44 & 10.5 & 406 & 46 & 11.3 \\
\hline OR (95\% Cl) & \multicolumn{3}{|c|}{$2.81(2.09-3.78)$} & \multicolumn{3}{|c|}{$3.21(2.28-4.53)$} & \multicolumn{3}{|c|}{$3.24(2.32-4.55)$} \\
\hline
\end{tabular}

Low birth weight Prevalence of low birth weight in the study sample was $7.3 \%$ in $2005,6.3 \%$ in 2008 , and $8 \%$ in 2011 . A significant association between low birth weight and anemia was observed only in 2011 (OR 1.74, Cl 1.04-2.92). Macrosomia was observed in all three years (5-10\%), although there was no significant association with anemia.

Breastfeeding In 2005, $28.1 \%$ of infants were exclusively breastfed for their first 6 months. Of those not exclusively breastfed for this period, $60.4 \%$ developed anemia, for a significant association between lack of exclusive breastfeeding through 6 months and appearance of anemia in that age group $(p=0.021)$ (Table 4$)$. In 2008 and $2011,29.8 \%$ and $34.1 \%$ of children, respectively, were exclusively breastfed for 6 months. In neither of these years was a significant association with anemia observed $(p=0.192$ and $p=$ 0.168 , respectively).

Table 4: Anemia prevalence in children aged 6-23 months, by exclusive breastfeeding and maternal anemia

\begin{tabular}{|c|c|c|c|c|c|c|c|c|c|}
\hline \multicolumn{10}{|c|}{ Exclusively breastfed for first 6 months } \\
\hline \multirow{3}{*}{ Group } & \multicolumn{3}{|c|}{$\begin{array}{c}2005 \\
\left(n=527^{*}\right)\end{array}$} & \multicolumn{3}{|c|}{$\begin{array}{c}2008 \\
\left(n=865^{\star}\right)\end{array}$} & \multicolumn{3}{|c|}{$\begin{array}{c}2011 \\
\left(n=880^{*}\right)\end{array}$} \\
\hline & \multirow{2}{*}{$\mathbf{N}$} & \multicolumn{2}{|c|}{ Anemic } & & \multicolumn{2}{|c|}{ Anemic } & & \multicolumn{2}{|c|}{ Anemic } \\
\hline & & $\mathbf{n}$ & $\%$ & $\mathbf{N}$ & $\mathbf{n}$ & $\%$ & $\mathbf{N}$ & $\mathbf{n}$ & $\%$ \\
\hline No & 379 & 229 & 60.4 & 607 & 237 & 39.0 & 580 & 224 & 38.6 \\
\hline Yes & 148 & 73 & 49.3 & 258 & 113 & 43.8 & 300 & 123 & 41.0 \\
\hline OR $(95 \% \mathrm{Cl})$ & \multicolumn{3}{|c|}{$1.57(1.05-2.34)$} & \multicolumn{3}{|c|}{$0.82(0.61-1.12)$} & \multicolumn{3}{|c|}{$0.91(0.67-1.22)$} \\
\hline \multicolumn{10}{|c|}{ Maternal anemia at onset of pregnancy } \\
\hline \multirow{3}{*}{ Group } & \multicolumn{3}{|c|}{$\begin{array}{c}2005 \\
\left(n=523^{*}\right)\end{array}$} & \multicolumn{3}{|c|}{$\begin{array}{c}2008 \\
\left(\mathrm{n}=856^{*}\right)\end{array}$} & \multicolumn{3}{|c|}{$\begin{array}{c}2011 \\
\left(n=869^{*}\right)\end{array}$} \\
\hline & \multirow{2}{*}{$\mathbf{N}$} & \multicolumn{2}{|c|}{ Anemic } & & \multicolumn{2}{|c|}{ Anemic } & & \multicolumn{2}{|c|}{ Anemic } \\
\hline & & $n$ & $\%$ & $\mathbf{N}$ & $n$ & $\%$ & $\mathbf{N}$ & $n$ & $\%$ \\
\hline Yes & 127 & 88 & 69.3 & 218 & 97 & 44.5 & 258 & 118 & 45.7 \\
\hline No & 396 & 211 & 53.3 & 638 & 250 & 39.2 & 611 & 227 & 37.2 \\
\hline OR $(95 \% \mathrm{Cl})$ & \multicolumn{3}{|c|}{$1.98(1.27-3.10)$} & \multicolumn{3}{|c|}{$1.24(0.90-1.72)$} & \multicolumn{3}{|c|}{$1.43(1.05-1.94)$} \\
\hline * Data unavail & able fo & som & childrer & & & & & & \\
\hline
\end{tabular}

In the 2011 survey, we also asked whether the child had ever been breastfed; $86.9 \%$ of children had had at least some breastfeeding and of these, $72.8 \%$ (63.2\% of sample) had been breastfed $\geq 4$ months. There was no difference between those who had been breast fed for $\geq 4$ months and those who had never been breastfed or had been for $<4$ months $(39.4 \%)$.

Maternal anemia In 2005, $24.1 \%$ of mothers were already anemic before pregnancy and $69.3 \%$ of their children developed anemia aged 6-23 months, a significant association ( $p=$ 0.001 ). In $2008,25.5 \%$ of mothers began pregnancy with anemia, and $44.5 \%$ of their children developed anemia aged $6-23$ months, but there was no significant association ( $p=0.168)$. A 
weak but significant association was observed in 2011, when $29.7 \%$ of mothers began pregnancy with anemia and of these, $45.7 \%$ of their children developed anemia aged $6-23$ months $(p=0.018)$ (Table 4).

Reported anemia was $5-10 \%$ higher in the second or third trimester of pregnancy than at onset in all three years. In 2005 and 2011, a weak but significant association was observed between development of maternal anemia in the second or third trimester of pregnancy and anemia prevalence in children, similar to the association observed in the first trimester.

\section{DISCUSSION}

Our results for 2005 showed higher anemia prevalence than the $29.1 \%$ reported in Reboso's 2002 study, but in 2005 most cases were mild, compared to only $22 \%$ mild in the 2002 study. Additionally, Reboso studied only urban children aged 6-24 months, limiting comparisons with that group.[18]

Decreased anemia prevalence in preschool children in eastern Cuba over the study period could be a result of enhanced maternal-child health interventions, such as antenatal care for pregnant women (aimed at reducing low birth weight and anemia during pregnancy), breastfeeding promotion education, and anemia detection (leading to treatment) in well child visits. [33,34]

Food-fortification strategies in the Plan could also be contributing to these results. However, while Corn Soya Blend (CSB) was distributed in the eastern provinces, it was found that only $0.6 \%$ of children aged 1-5 years were consuming it.[9] In addition, a UN World Food Programme literature review of CSB consumption in other populations revealed that the blend contains antinutrients that interfere with absorption of essential micronutrients, so it is not recommended for children aged $<2$ years, whose rapid growth means high needs for both macro- and micronutrients. CSB is now being reassessed with a view to reformulation to permit wider usage with greater benefits.[35]

Although educational activities were implemented in the five eastern provinces as part of the Plan and food interventions were similar in all, the drop in anemia prevalence was significant only in some provinces (Granma, Santiago de Cuba and Guantánamo). National studies conducted in 2007 in children aged $<3$ years found rates very similar to those of our 2008 study.[10] Differences in results between provinces-particularly the substantial increase in Las Tunas between 2008 and 2011-indicate need for further research on anemia risk factors, such as food availability and accessibility; incidence of bacterial, viral or parasitic infections; other nutrient deficiencies; obesity; and consumption of vitamin and mineral supplements.[36,37]

The relative decrease in anemia prevalence from 2005 to 2011 in the group aged 6-11 months could be due to the fact that most preventive actions have been conducted in this age group, including adoption of nutritional guidelines for children aged $<2$ years, which recommend introduction of complementary foods in addition to breastfeeding starting at age 6 months.[38]

Despite these signs of progress, from a public health perspective-and by WHO definitions-anemia prevalence in children aged $6-11$ months in the five eastern provinces puts it in the severe category. Contributing factors could be: unmet higher iron requirements at that age;[39] maternal anemia during pregnancy; inadequate provision of complementary foods to children aged $\geq 6$ months (only $64.2 \%$ in the eastern region in 2010 , although national nutrition guidelines recommend that breastfed infants aged $\geq 6$ months be given complementary foods). $[38,40]$ Further investigation is also needed to determine timing of umbilical cord clamping in Cuba; clamping earlier than one minute reduces the transfusion of cord blood that protects the infant against iron deficiency during the first months of life.[41]

Boys are reported to be more susceptible to iron deficiency than girls because of their more rapid growth in the first months of life,[42] but this was not observed in any of the three surveys we conducted.

The majority of Cuban preschoolers are cared for informally; only $28 \%$ of children aged $1-5$ years are enrolled in daycare centers. We found daycare enrollment to be protective against anemia; this may be related to the fact that they are fed at recommended intervals specific to their age and receive all food groups. In addition, hemoglobin testing is required before a child can be enrolled in daycare, providing an opportunity for early treatment to ensure the child starts day care with normal iron status.

In studies conducted in communities of Havana (unpublished data), we found that at-home mothers with preschool children tend to have more irregular meal schedules, which could result in the children not receiving all the nutrition critical for their development. In contrast to our results, a study in Recife, Brazil, found an anemia prevalence of $55.6 \%$ in children aged $<5$ years in public daycare centers, when a much lower prevalence was expected given the balanced diet and health care they received there. The authors acknowledged that they were missing important information about the children's nutritional status prior to enrollment, which may have influenced results.[43]

In the postnatal period, how rapidly iron is utilized depends on growth rate, iron ingestion and iron losses. More rapid weight gain confers higher risk of iron deficiency. Children with low birth weight suffer double jeopardy in this respect: they start with lower iron stores and their rapid postnatal growth increases their iron requirements. [42] Prevalence of low birth weight in all three surveys was slightly higher than the national average reported between 2005 and 2011 (5.3\% to 5.4\%).[44] The association observed between low birth weight and anemia in children aged 6-23 months suggests that actions to reduce low birth weight not only help prevent infant mortality, but also help prevent anemia at these ages. Similar results were found by Konstantyner in São Paulo, Brazil.[45]

Exclusive breastfeeding is recommended for the first six months of life, with introduction of complementary food beginning at six months and breastfeeding continuing up to two years.[46,47] There is some evidence that breastfeeding promotion efforts have been effective. The Multiple Indicator Cluster Survey (MICS) 2011 showed an increase in exclusive breastfeeding for six months in eastern Cuba, reaching 58.7\%.[40,48] Similarly, in this study, a steady increase was observed from 2005 to 2011, although breastfeeding rates were lower than those reported in the MICS surveys. This difference may be explained by differing data collec- 
tion methods: MICS asked about children aged 0-5 months who were being exclusively breastfed at time of interview,[40] while our study collected the information retrospectively, about children who were already aged $\geq 6$ months, the age threshold for inclusion in the study.

Introduction of other liquid or solid foods during the first six months of life can interfere with absorption of iron from breast milk[49] and can also lead to an increase in respiratory symptoms.[47] We found a statistically significant protective effect of six months' exclusive breastfeeding only in 2005. The results of Brazil's National Health Demographics study in 2006, which found no association between breastfeeding for four months and anemia in children,[50] are consistent with our 2011 finding of no difference in anemia prevalence between age subgroups of infants breastfed for $<6$ months, suggesting a threshold effect.

Kramer and Kakuma's systematic review of optimal breastfeeding duration found scant data on iron deficiency in developing countries, where iron stores in newborns can be suboptimal; they suggested that exclusive breastfeeding without iron supplements in the first months may compromise hematological status.[51] This could be a factor in the high percentage ( $>40 \%$ in all three years) of children aged 6-23 months in our study who were exclusively breastfed for six months and then became anemic.

Similar results to ours were found in a cross-sectional study conducted in Pernambuco, Brazil, which examined $\mathrm{Hb}$ levels in the mother, exclusive breastfeeding for six months, and hematological status in the child aged $\leq 6$ months. The study found that one of the factors contributing to low $\mathrm{Hb}$ levels in the child was maternal anemia, highlighting the need to prevent anemia before, during and after pregnancy.[52] Our research found an association between maternal anemia at onset of and during pregnancy with subsequent anemia in children aged 6-23 months, suggesting that actions for anemia prevention in women of childbearing age constitute an important strategy to help reduce anemia prevalence in preschool children. For this reason, as part of the national Plan, a free nutritional supplement (MUFER) has been formulated for women of childbearing age with anemia risk factors, such as menorrhagia or recent surgery.[16]

Better estimates of iron status can have an important effect on identifying the real prevalence of functional iron deficiency, as well as on design and implementation of interventions to improve iron nutrition.[53] While it is accepted that in populations with high anemia prevalence, the primary cause is iron deficiency, other biochemical tests are needed to understand the whole picture. Deficiencies in other nutritional micronutrients may also contribute: vitamin A, folic acid, cobalamin, riboflavin, vitamin C, copper and zinc. Similarly, non-nutritional causessuch as infection, inflammation, hemoglobinopathies and chronic illnesses-can contribute to development and perpetuation of anemia. $[8,36,47]$

The benefits of an intervention are never uniform, and understanding these variations requires generating hypotheses concerning the underlying biology, so as to better identify lessons from a limited number of studies. A growing body of evidence suggests that the effects of iron interventions differ qualitatively depending on the individual's pre-existing iron status.[54] Further- more, additional research is needed based on interventions and basic sciences, particularly to explore interactions between iron status and infections.[55]

Our study has several limitations. First, only hemoglobin levels were used to determine anemia, while other iron-deficiency indicators (ferritin, erythrocyte indices, transferrin saturation index, zinc protoporphyrin) could not be assessed, limiting a more profound understanding of causes. Nevertheless, we consider hemoglobin estimates important for monitoring the effectiveness of national Plan interventions to prevent and control anemia.

Second, the absence of daycare centers in the rural areas of many municipalities constrained our analysis of the possible anemia-protective effect of organized day care. Third, data on maternal anemia during pregnancy and breastfeeding duration were all self reported, so recall bias is a possibility. Fourth, because we were unable to determine the exact size of the age-sex strata, it was difficult to calculate weighting factors for analysis of complex samples. However, the difference between the two sampling schemes has more to do with variance than with point estimates, which are similar.

Despite these constraints, the study is important because it has provided anemia prevalence data for Cuba's eastern provinces in three different years over a decade. This information is valuable for understanding Cuba's progress in anemia prevention and control. It also identified factors associated with anemia that can help redirect the national Plan's prevention and control strategies.

In order to evaluate the strategies' impact, new studies are needed to determine presence of other causes of anemia, such as vitamin A or other micronutrient deficiency, malnutrition from obesity, and inflammation from recurrent infections (bacterial or parasitic). Multivariate analyses are required to assess the effect of the entire set of factors influencing anemia risk.

\section{CONCLUSIONS}

Cuba's strategies for anemia prevention and control have had a beneficial effect in the area studied. Anemia prevalence in Cuba's eastern region has steadily decreased, but it is still classified as a moderate public health problem, with greatest impact in children aged 6-23 months. Moreover, it is classified as a severe problem for the group aged 6-11 months in this region. Recommendations include continuation and strengthening of anemia control actions for women of childbearing age, such as exclusive breastfeeding for six months and compliance with Cuban guidelines on complementary feeding for children $\leq 2$ years. Further research is needed into the causes of anemia in the preschool population.

\section{ACKNOWLEDGMENTS}

We thank the nutritionists, dieticians and additional personnel of the Provincial Hygiene and Epidemiology Centers for their participation in the sampling and survey processes: in Las Tunas, Irelis Tamayo and Osmani Méndez; in Holguín, Joan Araluce, Clara Rosa Brau and Jimmy Campos; in Santiago de Cuba, Jorge Ruíz; and in Guantánamo, Esneiva Venereo. Thanks to Dr Isabel Barroso and to José Reboso for statistical design, and to the UN World Food Programme office in Cuba for logistical and organizational support. -1 - 


\section{REFERENCES}

1. World Health Organization; Center for Disease Control and Prevention. Worldwide prevalence of anaemia 1993-2005: WHO global database on anaemia [Internet]. Geneva: World Health Organization; 2008 [cited 2010 Oct 3]. 51 p. Available from: http://whqlibdoc.who.int/publica tions/2008/9789241596657 eng.pdf

2. Georgieff MK. Nutrition and the developing brain: nutrient priorities and measurement. Am J Clin Nutr [Internet]. 2007 [cited 2010 Feb 26];85(2 Suppl):614-20. Available from: http://www.ajcn .org/content/85/2/614S.full.pdf

3. Widdowson EM, Spray CM. Chemical development in-utero. Arch Dis Child [Internet]. 1951 Jun [cited 2012 Jun 19];26(127):205-14. Available from: http://www.ncbi.nlm.nih.gov/pmc/articles/ PMC1988372/pdf/archdisch01420-0013.pdf

4. Beard J. Why iron deficiency is important in infant development. J Nutr [Internet]. 2008 Dec [cited 2011 Mar 4];138(12):2534-6. Available from: http://jn.nutrition.org/content/138/12/2534.full.pdf

5. González P. Anemia y déficit de hierro en niños y adolescentes. Rev Anemia. 2009 [cited 2010 Jul 6];2(2):13-20. Available from: http://www.revista anemia.org/presentacion-pdf-revista-anemia .php?fileid=r0202\&filepdf=gr0pdf2. Spanish

6. Lozoff B, Corapci F, Burden M, Kaciroti N, Angulo-Barroso R, Sazawal S, et al. Preschool-aged children with iron deficiency anemia show altered affect and behaviour. J Nutr [Internet]. 2007 [cited 2011 Mar 4];137(3):683-9. Available from: http:// jn.nutrition.org/content/137/3/683.full.pdf

7. Carter RC, Jacobson JL, Burden MJ, ArmonySivan R, Dodge NC, Angelilli ML, et al. Iron deficiency anemia and cognitive function in infancy. Pediatrics [Internet]. 2010 [cited 2011 Mar 30];126(2):427-34. Available from: http://pedia trics.aappublications.org/content/126/2/e427.full .pdf+html

8. World Health Organization; United Nations University. Iron deficiency anemia. Assessment, prevention and control. A guide for program managers [Internet]. Geneva: World Health Organization; c2001 [cited 2005 Dec 26]. 114 p. Available from: www.who .int/nutrition/publications/en/ida_assessment prevention_control.pdf

9. Pita G, Jiménez $\mathrm{S}$. La anemia por deficiencia de hierro en la población infantil de Cuba. Brechas por cerrar. Rev Cubana Hematol Inmunol Hemoter [Internet]. 2011 [cited 2011 Sep 6];27(2):17995. Available from: http://scielo.sld.cu/pdf/hih/ v27n2/hih03211.pdf. Spanish.

10. United Nations Children's Fund; Nutrition and Food Hygiene Institute (CU). Intervenciones para la prevención de la anemia por deficiencia de hierro en infantes menores de tres años. Puré de frutas fortificados. Experiencia cubana. Havana: Food Industry Research Institute (CU); 2011. Spanish.

11. Horton S. The economics of nutritional intervention. In: Semba R, Bloem M, editors. Nutrition and Health in Developing Countries. 2nd ed. New Jersey: Humana Press; 2008. p. 859-71.

12. Martorell R. Forging effective strategies to combat iron deficiency. Panel Discussion: Regional Action Priorities. J Nutr [Internet]. 2002 [cited 2011 Mar 4];132(4 Suppl):S871-S4. Available from: http://jn.nutrition.org/content/132/4/871S .full.pdf

13. Lamounier JA, Capanema FD, Rocha Dda S, de Oliveira JE, da Silva MC, de Almeida CA. Iron fortification strategies for the control of childhood anemia in Brazil. J Trop Pediatr [Internet]. 2010 Dec [cited 2011 Jun 10];56(6):448-51. Available from: http://cdn.intechopen.com/pdfs/36936/ln Tech-Iron_food_fortification_for_the_control of_childhood_anemia_in_brazil.pdf
14. Nutrition and Food Hygiene Institute (CU); United Nations Children's Fund. Intervenciones para la prevención de la anemia por deficiencia de hierro en infantes menores de tres años. Puré de frutas fortificados, experiencia cubana. Havana: United Nations Children's Fund; 2011. Spanish.

15. Pita G, Basabe B, Díaz ME, Mercader O, Reboso J, Carrillo $\mathrm{M}$, et al. Progreso en la reducción de la anemia en niños de un año de edad en La Habana entre los años 2005 y 2007. Nutr Clín Diet Hosp [Internet]. 2012 [cited 2012 Feb 12];32(1):13-25. Available from: http://www.nutri cion.org/publicaciones/revista_2012_01/PRO GRESO.pdf. Spanish.

16. Ministry of Public Health (CU). Plan integral para la prevención y el control de la anemia por deficiencia de hierro en Cuba. Havana: Ministry of Public Health (CU); 2008. Spanish.

17. Terry B, González R, Padrón M, Terry S. Implementación del plan nacional para la prevención y control de la anemia en Cuba. Nutr Hosp. 2010;25 Suppl 1:88. Spanish.

18. Reboso J, Jiménez $S$, Monterrey $P$, Macías $C$, Pita G, Selva L, et al. Diagnóstico de la anemia por deficiencia de hierro en niños de 6 a 24 meses y de 6 a 12 años de edad de las provincias orientales de Cuba. Rev Esp Nutr Comunitaria [Internet]. 2005 [cited 2011 Apr 4];11(2):60-8. Available from: http://www.nutri cioncomunitaria.org/BDProtegidos/Anemia $\% 20$ Cuba_I_1155030887706.pdf. Spanish.

19. World Food Programme [Internet]. Rome: World Food Programme; c2013 [cited 2010 Oct 25]. Apoyo al Plan Nacional para la Prevención y Control de la Anemia en niños menores de 5 años de las cinco provincias orientales (20082012). Proyecto de Desarrollo Cuba 10589. Available from: http://www.wfp.org/countries/ cuba. Spanish.

20. United Nations. Programa conjunto. Apoyo a la lucha contra la anemia en grupos vulnerables en Cuba. Ventanilla Temática Infancia, seguridad alimentaria y nutrición [Internet]. New York: United Nations; 2009 [cited 2010 Oct 20]. 81 p. Available from: https://coin.fao.org/cms/ media/2/12565779790190/cuba pc apoyo a la_lucha_contra_la_anemia_2009.pdf. Spanish.

21. Selva LN, Ochoa AA. Acciones para la prevención y control de la anemia por deficiencia de hierro en niños hasta cinco años. Rev Cubana Salud Publica [Internet]. 2011 [cited 2013 May 20];37(3):200-6. Available from: http://scielo.sld cu/pdf/rcsp/v37n3/spu03311.pdf. Spanish.

22. Physical Planning and Urban Design Institute (CU). Análisis y Cartografía de la Vulnerabilidad a la Inseguridad Alimentaria en Cuba. Havana: World Food Programme; 2001. p. 139. Spanish.

23. Galván M, Amigo H. Programas destinados a disminuir la desnutrición crónica. Una revisión en América Latina. Arch Latinoam Nutr [Internet]. 2007 [cited 2012 Jan 19];57(4):316-26. Available from: http://www.scielo.org.ve/pdf/alan/v57n4/ art03.pdf. Spanish.

24. Yip R, Ramakrishnan U. Forging effective strategies to combat iron deficiency. Experience and challenges in developing countries. J Nutr [Internet]. 2002 [cited 2011 Mar 4];132(4 Suppl):S820S4. Available from: http://jn.nutrition.org/ content/132/4/827S.full.pdf

25. Lynch S. Improving the assessment of iron status. Am J Clin Nutr [Internet]. 2011 Jun [cited 2011 Jun 22];93(6):1188-9. Available from: http:// www.ajcn.org/content/93/6/1188.full.pdf

26. National Statistics Bureau (CU). Proyecciones estimadas para la población cubana. Havana: National Statistics Bureau (CU); 2004. Spanish.

27. United Nations Children's Fund. Glosario de términos sobre nutrición. Un recurso para comu- nicadores [Internet]. New York: United Nations Children's Fund; 2012 Apr [cited 2013 Jun 18]. 15 p. Available from: http://www.unicef.org/lac/ Nutrition Glossary ES.pdf. Spanish.

28. World Health Organization; United Nations Children's Fund. Indicators for assessing infant and young child feeding practices. Part 1 Definitions [Internet]. Washington, DC: World Health Organization; 2008 [cited 2013 Jan 15]. 20 p. Available from: http://whqlibdoc.who.int/publica tions/2008/9789241596664_eng.pdf

29. Blood hemoglobin photometer HemoCue 2011 [Internet]. Angelhom (SW): HemoCue; c2011 [cited 2013 Jan 22]. Available from: http://www .hemocue.com

30. Romero A, Naviera E, Gómez JF, Ramírez G, Muñoz M. Utilidad de la medición de hemoglobina con el HemoCue B Hemoglobin en el manejo de la anemia. Revisión de nuestra experiencia en distintos contextos. Anemia. 2009 Jan;2(2):7382. Spanish.

31. de A Paiva A, Rondó P, de B Silva S, Latorre M. Comparison between the HemoCue and an automated counter for measuring hemoglobin. Rev Saude Publica [Internet]. 2004 Aug [cited 2009 Jun 24];38(4):585-7. Available from: http://www.scielosp.org/scielo.php?script=sci _arttext\&pid=S0034-89102004000400017\&Ing= en\&nrm=iso\&tlng=en

32. Spiegel MR. Teorías y Problemas de Estadística. Estimaciones de Intervalos de Confianza para proporciones. 4th ed. Havana: Editorial Pueblo y Educación; 1977. Spanish.

33. Nutrinet.org [Internet]. Havana: World Food Program; c2013 [cited 2013 Jul 4]. Experiencias exitosas. Programa Nacional Materno Infantil, Programa de suplementación con "Prenatal" en la Atención Primaria de Salud y Hogares Maternos 2012. Available from: http://cuba.nutrinet org/cuba/experiencias-exitosas. Spanish.

34. Grupo Nacional de Puericultura Departamento Materno Infantil. Consulta de puericultura [Internet]. Havana: Ministry of Public Health (CU); 2011 [cited 2013 Jul 4]. Available from: http:// files.sld.cu/puericultura/files/2012/02/libro-con sulta-de-puericultura-20111.pdf. Spanish.

35. van Hees J, de Pee S, Bloem M, Heines E, Acharya $P$, van den Briel T. Ten minutes to learn about Improving Corn Soy Blend and other fortified blended foods, why and how. Sight and Life. 2008;3 Suppl:S26-S31.

36. Thurnham D. Monitoring Anemia-Control Program. Sight and Life. 2009:1:59-66.

37. Thurnham D. Micronutrient deficiencies and affluence. Sight and Life [Internet]. 2009 [cited $2011 \mathrm{Apr} 11$ ];(3). Available from: http://www.sight andlife.org/images/stories/pageimages/content/ magazine/03_2009/sl_mag_3-2009.pdf

38. Jiménez S, Pineda S, Sánchez R, Rodríguez A, Domínguez Y. Guías Alimentarias para niñas y niños cubanos hasta 2 años de edad. Documento técnico para los equipos de Salud. Havana: Nutrition and Food Hygiene Institute (CU); 2009 [cited 2012 Jun 18]. Available from: http://www .inha.sld.cu/doc_pdf/guias_menores_dos_anos. pdf. Spanish.

39. Beard J. Recent evidence from human and animal studies regarding iron status and infant development. J Nutr [Internet]. 2007 Feb [cited 2011 Mar 4];137(2): 524S-30S. Available from: http://jn.nutrition.org/content/137/2/524S.full.pdf

40. National Statistics and Medical Records Division (CU); United Nations Children's Fund. Encuesta de Indicadores Múltiples por Conglomerado [Internet]. Havana: Ministry of Public Health; 2012 Jan [cited 2012 May 14]. 132 p. Available from: http://files.sld.cu/dne/files/2012/05/encue sta-de-indicadores-multiples-e.pdf. Spanish. 
41. Arturo L. Prácticas que salvan vidas: Clampeo oportuno de cordón umbilical y lactancia precoz. Boletín OPS [Internet]. 2009 [cited 2013 Oct 14]; [about 4 screens];(15). Available from: http://new .paho.org/bulletins/index.php?option=com_con tent\&task=view\&id=393\&ltemid=308. Spanish .

42. Chaparro CM. Setting the stage for child health and development: prevention of iron deficiency in early infancy. J Nutr [Internet]. 2008 Dec [cited 2011 Mar 4];138(12):2529-33. Available from: http://jn.nutrition.org/content/138/12/2529.full .pdf+html

43. Vieira AC, Diniz AS, Cabral PC, Olivera RS, Lóla MMF, Silva SMM, et al. Nutritional assessment of iron status and anemia in children under 5 years old at public daycare centers. J Pediatr (Rio J) [Internet]. 2007 [cited 2011 Mar 15];83(4):370-6. Available from: http:/www.jped.com.br/ArtigoDe talhe. aspx? varArtigo $=1680$ \&idioma $=p t-B R$

44. National Statistics Bureau (CU). Educación en cifras. Cuba 2011. Havana: Ministry of Public Health (CU); 2012 [cited 2012 April 30]. 3 p. Available from: http://www.one.cu/publicacione s/03estadisticassociales/Educacion $\% 20$ en $\% 20$ Cifras\%20Cuba\%202010/circulosinfantiles.pdf. Spanish.

45. Konstantyner T, Taddei JA, Oliveira MN, Palma $D$, Colugnati FA. Isolated and combined risks for anemia in children attending the nurseries of daycare centers. J Pediatr (Rio J) [Internet]. 2009 May-Jun [cited 2010 Mar 13];85(3):20916. Available from: http://www.jped.com.br/Arti goDetalhe. aspx?varArtigo=1957\&idioma=pt-BR. English, Portuguese.

46. World Health Organization; United Nations Children's Fund. Global strategy for infant and young child feeding [Internet]. Geneva: World Health Organization; 2003 [cited 2012 Jan 19]. 30 p. Available from: http://whqlibdoc.who.int/publications/2003/9241562218.pdf

47. Fewtrell MS, Morgan JB, Duggan C, Gunnlaugsson G, Hibberd PL, Lucas A, et al. Optimal duration of exclusive breastfeeding: what is the evidence to support current recommendations. Am J Clin Nutr [Internet]. 2007 [cited 2010 Feb 17];85(2):635S-38S. Available from: http://www .ajcn.org/content/85/2/635S.full.pdf

48. National Statistics and Medical Records Division (CU); United Nations Children's Fund. Encuesta de Indicadores Múltiples por Conglomerados [Internet]. Havana: Ministry of Public Health (CU); 2006 [cited 2012 May 14]. 96 p. Available from: http://files.sld.cu/dne/files/2012/03/encue sta_conglomerados_2006.pdf. Spanish.

49. Lutter CK. Iron deficiency in young children in lowincome countries and new approaches for its prevention. J Nutr [Internet]. 2008 Dec [cited 2011 Mar 4];138(12):2523-8. Available from: http://jn.nutrition .org/content/138/12/2523.full.pdf
50. Konstantyner T, Oliveira TCR, de Aguiar TA. Risk Factors for Anemia among Brazilian Infants from the 2006 National Demographic Health Survey. Anemia [Internet]. 2012 [cited 2012 Jun 19];2012:850681. Available from: http://www .ncbi.nlm.nih.gov/pmc/articles/PMC3286880/pdf/ ANE2012-850681. pdf?tool=pmcentrez

51. Kramer MS, Kakuma R. The optimal duration of exclusive breastfeeding. A systematic review. Adv Exp Med Biol. 2004;554:63-77.

52. Teixeira ML, Lira PI, Coutinho SB, Eickmann SH, Lima MC. Influence of breastfeeding type and maternal anemia on hemoglobin concentration in 6-month-old infants. J Pediatr (Rio J) [Internet]. 2010 Jan-Feb [cited 2010 Nov 29];86(1):65-72. Available from: www.jped.com.br/ArtigoDetal he.. spp ?varArtigo $=2057$ \&idioma $=$ pt-BR

53. Lynch S. Improving the assessment of iron status. Am J Clin Nutr [Internet]. 2011 [cited 2011 Jun 22];93(6):1188-9. Available from: http:// www.ajcn.org/content/93/6/1188.full.pdf

54. Salim-Ur-Rehman, Huma N, Tarar OM, Shah WH. Efficacy of non-heme iron fortified diets: a review. Crit Rev Food Sci Nutr [Internet]. 2010 [cited 2012 Jan 19];50(5):403-13. Available from: http://www.ingentaconnect.com/content/ tandf/bfsn/2010/00000050/00000005/art00003

55. Stoltzfus R. Research needed to strengthen science and programs for the control of iron deficiency and its consequences in young children. J Nutr [Internet]. 2008 [cited 2011 Mar 4];138(12):2542-6. Available from: http:// jn.nutrition.org/content/138/12/2542.full.pdf

\section{THE AUTHORS}

Gisela M. Pita Rodríguez (Corresponding author: hematologia@sinha.sld.cu), physician specializing in clinical biochemistry with a master's degree in environmental health. Associate professor and researcher, Nutrition and Food Hygiene Institute (INHA), Havana, Cuba.

Santa Jiménez Acosta, physician specializing in nutrition with a doctorate in health sciences. Full professor and senior researcher, INHA, Havana, Cuba.

Beatriz Basabe Tuero, biochemist with a master's degree in public health nutrition and a doctorate in food sciences. Associate professor and researcher, INHA, Havana, Cuba.

René G. García Roche, physician specializing in health statistics. Associate professor and researcher, National Hygiene, Epidemiology and Microbiology Institute (INHEM), Havana, Cuba.

Consuelo Macías Matos, biochemist with a doctorate in chemical sciences. Senior researcher, INHA, Havana, Cuba.

Lisette Selva Suárez, physician specializing in nutrition and food hygiene, Provincial Hygiene and Epidemiology Center, Holguín, Cuba.

Clarisa Hernández Fernández, physician with dual specialties in family medicine and hygiene and epidemiology, Provincial Hygiene and Epidemiology Center, Holguín, Cuba.

Margarita Cruz Jorge, dietician, Provincial Hygiene and Epidemiology Center, Granma, Cuba.

Roxana Herrera Charro, pediatrician with a master's degree in nutrition, Provincial Hygiene and Epidemiology Center, Guantánamo, Cuba.

Regla O'Farrill López, physician specializing in nutrition and food hygiene, Provincial Hygiene and Epidemiology Center, Granma, Cuba.

Isabel Calderius Espinosa, chemist, Provincial Hygiene and Epidemiology Center, Granma, Cuba.

Karelia Paulí Echeverría, physician specializing in hygiene and epidemiology, Provincial Hygiene and Epidemiology Center, Santiago de Cuba.

Moraima Leyva Ávila, dietetic technician, Provincial Hygiene and Epidemiology Center, Las Tunas, Cuba.

Caridad Arocha Oriol, laboratory technician, INHA, Havana, Cuba.

Dania Herrera Javier, biologic processes technician, INHA, Havana, Cuba.

Submitted: February 20, 2013

Approved for publication: January 14, 2014

Disclosures: None 